\title{
Effect of Physical and Chemical Activation on Arsenic Sorption Separation by Grape Seeds-Derived Biochar
}

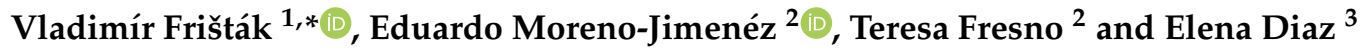 \\ 1 Department of Chemistry, Faculty of Education, Trnava University in Trnava, 91843 Trnava, Slovak Republic \\ 2 Department of Agricultural and Food Chemistry, Faculty of Sciences, Universidad Autónoma de Madrid, \\ 28049 Madrid, Spain; eduardo.moreno@uam.es (E.M.-J.); teresa.fresno@uam.es (T.F.) \\ 3 Chemical Engineering Department, Faculty of Sciences, Universidad Autónoma de Madrid, 28049 Madrid, \\ Spain; elena.diaz@uam.es \\ * Correspondence: fristak.vladimir.jr@gmail.com; Tel.: +421-33-592-1459
}

Received: 22 September 2018; Accepted: 5 December 2018; Published: 19 December 2018

check for updates

\begin{abstract}
The utilization of carbon-rich pyrolysis materials in the separation processes of metalloids plays a crucial role in analytes pre-concentration techniques and opens a burning issue in new sorbents development. This study characterized the effect of physical and chemical activation with subsequent iron impregnation of grape seed-derived biochar on sorption removal of As from model aqueous solutions. Sorbents that were produced in slow pyrolysis process at $600{ }^{\circ} \mathrm{C}$ were characterized by SEM, elemental, and specific surface area analysis. Sorption separation of As by the studied materials was characterized as on contact time and an initial concentration dependent process reaching sorption equilibrium in $1440 \mathrm{~min}$. Air activated biochar (A1GSBC) showed about 7.7 times and $\mathrm{HNO}_{3}$ activated biochar (A2GSBC) about 6.8 times higher values of $Q_{\max }$ as compared to control (GSBC). A1GSBC and A2GSBC can be easily and effectively regenerated by alkali agent in several cycles. All of these results showed the practical use of the activation process to produce effective sorption materials with increased surface area and improved sorption potential for anionic forms separation from liquid wastes.
\end{abstract}

Keywords: arsenic; separation; biochar; pyrolysis; activation

\section{Introduction}

Arsenic contamination of agricultural soils, grazing soils, and ground waters represents a serious problem in several countries of Europe, such as Spain, France, Czech Republic, and Slovakia [1]. European Union (EU) drinking water directives refer very strictly how to meet metalloid standards. Conventional technologies of arsenic removal from liquids include oxidation/precipitation, coagulation/co-precipitation, sorption, and ion exchange [2]. Major oxidation/precipitation methods, such as air and chemical oxidation, represent relatively simple, low-cost, but slow processes. Additionally, alum coagulation, iron coagulation, and lime softening are very simple in operation, potentially low-cost, but are characterized by toxic sludges production and low arsenic removal [3]. Sorption separation represents a promising method to remove and concentrate selected metals/metalloids from liquid wastes and contaminated effluents [4]. On the other hand sorption separation plays crucial role in As-analytical determination. Because of the very low concentration of arsenic in environmental samples, pre-concentration methods and subsequent sensitive techniques of arsenic quantification are required [5]. The choice of an appropriate sorbent in procedure of solid phase extraction (SPE) is a critical to obtain the full recovery of chemical species. Several various sorbents have been used in As pre-concentration studies [6-8]. In recent times, activated carbon-, biochar-, and pyrogenic carbonaceous material-based sorbents have been paid 
attention for application in separation processes of As from aqueous solutions and liquid media [9-11]. Biochar as a solid product of biomass termochemical conversion provides significant material properties, such as high porosity, negative surface charge, surface area, and stability [12]. Lehmann and Joseph [13] showed biochar as an important tool in the remediation and purification of contaminated liquid wastes and aqueous solutions. Suitable pre-treatment and post-treatment of pyrogenic material can alter the crucial physico-chemical properties, surface morphology of sorbent, and thus enhance the sorption potential and selectivity for individual chemical species. Our previous studies $[10,12,14]$ showed relevant roles of surface chemical modification by Fe-impregnation in sorption separation several cationic and anionic chemical forms. On the other hand physical activation by steam, heat, freeze,-thawing cycles can alter sorbent properties as well [15-17]. However, the detailed information about combined effect of physical and chemical modification of sorbent is still missing.

Based on these scenarios, the aim of the present research was to compare grape seed-derived biochar and physically and chemically activated analogues for As (V) sorption separation from model aqueous solutions.

\section{Materials and Methods}

\subsection{Biochar Origin, Pyrolysis and Activation Process}

Grape seeds (GS) that were used as precursor were from the red wine variety "Tinta de Toro" harvested in Toro (Zamora, Spain). The size of bones was $2-4 \mathrm{~mm}$. Detail preparation design was described in work Mena et al. [18]. Briefly, after grape bones were washed in deionized water and dried, feedstock was pyrolysed in lab-scale quartz furnace (Carbolite CB, HTR, 11/150P8) at $600{ }^{\circ} \mathrm{C}$ for $2 \mathrm{~h}$ with $\mathrm{N}_{2}$ atmosphere to ensure anoxic conditions and stable heating rate. The resulting char is labeled as GSBC. This material has been activated at $400{ }^{\circ} \mathrm{C}, 2 \mathrm{~h}$ by air $(2 \mathrm{NL} / \mathrm{min})$, and the resulting material is identified as air activated biochar (A1GSBC). The second activation process was realized by $\mathrm{HNO}_{3}(6 \mathrm{~N}, 1 / 10 \mathrm{w} / v, 20$ min contact time), followed by washing with deionized water to reach neutral $\mathrm{pH}$. Obtained biochar is labeled as $\mathrm{HNO}_{3}$ activated biochar (A2GSBC). Both activated GSBC were Fe-impregnated by $\mathrm{FeNO}_{3}$, dried at $60^{\circ} \mathrm{C}, 12 \mathrm{~h}$, and calcinated at $300{ }^{\circ} \mathrm{C}, 4 \mathrm{~h}$.

\subsection{Sorbent Characterization}

The $\mathrm{pH}$ values of studied sorbents were measured after mixing the samples with deionized water (ratio 1/15: $\mathrm{m} / \mathrm{v}$ ) for 1 and $1 \mathrm{~h}$ of stabilization. Electrical conductivities (EC) of the samples were measured in deionized water $(1: 10 \mathrm{~m} / \mathrm{v})$ after $24 \mathrm{~h}$ of mixing. The morphology of A1GSBC and A2GSBC were analyzed by SEM with a Hitachi S-3000N apparatus. Imaging was performed in the high vacuum mode under an accelerating voltage of $20 \mathrm{kV}$, while using secondary and backscattered electrons. The total C, H, N, S, O contents were determined by Elemental Analyser (CHNS-O EA 1108, Carlo Erba Instruments, Milan Italy). Total As and Fe concentrations in GS, GSBC, A1GSBC, and A2GSBC were quantified using inductively coupled plasma mass spectrometry (ICP-MS, PerkinElmer, ElanDRCe 9000, Waltham, MA, USA) after wet digestion with application $\mathrm{HNO}_{3}$ and $\mathrm{H}_{2} \mathrm{O}_{2}$ method [19]. Specific surface areas and micropores volume of the samples were measured by the technique of nitrogen adsorption and desorption (SORPTOMATIC 1990, Milan, Italy), followed by Brunauer-Emmett-Tellers (BET) model evaluation.

\subsection{Experimental Design of Sorption Experiments}

The process of As $(V)$ sorption separation from single component system by GSBC, A1GSBC, and A2GSBC was characterized by the batch equilibration method [20]. Sorption kinetic experiments were realized by suspending of $150 \mathrm{mg} \mathrm{GSBC}, \mathrm{A} 1 \mathrm{GSBC}$, and A2GSBC in $30 \mathrm{~mL}$ of reaction solution with initial concentration $100 \mathrm{mg} / \mathrm{L} \mathrm{AsO}_{4}{ }^{3-}$ (54 mg/L As (V)) Experimental conditions pH 5.5-6.0, contact time: $10-2880 \mathrm{~min}$, rotation: $120 \mathrm{rpm}$, temperature: $22 \pm 1{ }^{\circ} \mathrm{C}$. Equilibrium sorption experiments were carried out under the following conditions: $\mathrm{C}_{0} \mathrm{AsO}_{4}{ }^{3-} 10-100 \mathrm{mg} / \mathrm{L}$ (5.4-54 mg/L 
As (V)), s/L ratio: 1:200, pH 5.5-6.0, contact time: 1440, rotation: $120 \mathrm{rpm}$, temperature: $22 \pm 1{ }^{\circ} \mathrm{C}$. After shaking, the liquid and solid phases were separated. Residual solution was filtered through $0.45 \mu \mathrm{m}$ pore size membrane filter and spiked with $50 \mu \mathrm{L}$ of $\mathrm{HNO}_{3}$. Filters were tested for retaining of As before application. Arsenic was quantified by the method of hydride generation coupled to an atomic fluorescence spectrometry (HG-AFS, PS Analytical, 10.055, Millennium Excalibur system). For the hydride generation, a matrix of $\mathrm{HCl} 25 \%(v / v)+$ ascorbic acid $0.2 \%(w / v)+\mathrm{KI}$ $1 \%$, and a reductant based on the mixture of $\mathrm{NaBH}_{4} 0.7 \%$ and $\mathrm{NaOH} 0.4 \%$ were used.

Sorption of As was calculated according Equation (1):

$$
Q_{e q}=\left(C_{0}-C_{e q}\right) V / w
$$

where $Q_{e q}$ is the As uptake (mg/g), $C_{0}$ is the initial liquid-phase concentrations of As $(\mathrm{mg} / \mathrm{L}), C_{e q}$ is the equilibrium liquid-phase concentrations of $\mathrm{As}(\mathrm{mg} / \mathrm{L}), V$ is the volume $(\mathrm{L})$, and $w$ is the amount of biochar (g).

\subsubsection{Applied Mathematical Models of Kinetic Study}

For investigation of sorption kinetics, three kinetic models were used [10]. Parameters were obtained by the program MicroCal Origin 8.0 Professional (OriginLab Corporation, Northampton, MA, USA).

The pseudo-first-order equation can be defined as:

$$
Q_{t}=Q_{e q}\left(1-e^{-k 1 t}\right)
$$

in which $Q_{t}$ is the amount of As sorbed at time $t(\mathrm{mg} / \mathrm{g}), Q_{e q}$ is its value at equilibrium $(\mathrm{mg} / \mathrm{g})$, and $k_{1}$ is the rate constant of pseudo-first-order process $(1 / \mathrm{min})$.

The pseudo-second-order model can be defined as:

$$
Q_{t}=\left(Q_{e q}^{2} k_{2} t\right)\left(1+k_{2} t Q_{e q}\right)^{-1}
$$

in which $k_{2}$ is the rate constant of the pseudo-second-order process $\left(\mathrm{g} / \mathrm{mg} \mathrm{min}^{-1}\right)$ and $Q_{t}$ and $Q_{e q}$ have the same meaning as in the pseudo-first-order equation.

Pseudo-n-order model can be defined as:

$$
Q_{t}=Q_{e q}-\left[Q_{e q}^{1-n}-(1-n) k_{n} t\right]^{1 /(1-n)}
$$

in which $k_{3}$ is the rate constant of the pseudo-n-order process $\left(\mathrm{g} / \mathrm{mg} \mathrm{min}^{-1}\right), n$ is the order of rate equation, and $Q_{t}$ and $Q_{e q}$ have the same meaning as in pseudo-first-order equation.

\subsubsection{Applied Mathematical Models of Adsorption Isotherms}

The obtained equilibrium sorption data were analysed by mathematical equations of adsorption models with the terms of Langmuir, Freundlich, and Sips [10]. Parameters of adsorption isotherms were calculated by non-linear regression analysis using the program MicroCal Origin 8.0 Professional (OriginLab Corporation, Northampton, MA, USA).

Langmuir is the simplest type of theoretical adsorption model. The isotherm is given by equation:

$$
Q_{\mathrm{eq}}=\left(b Q_{\max } C_{e q}\right) /\left(1+b C_{e q}\right)
$$

where $Q_{e q}$ is the amount of sorbed As at equilibrium $(\mathrm{mg} / \mathrm{g}), b$ is the isotherm coefficient characterizing biochar affinity to As ions in solution $(\mathrm{L} / \mathrm{mg}), Q_{\max }$ is the maximum sorption capacity at saturated biochar binding sites $(\mathrm{mg} / \mathrm{g})$, and $C_{e q}$ represents the As equilibrium concentration in solution $(\mathrm{mg} / \mathrm{L})$. 
The Freundlich adsorption model is commonly used to describe the adsorption process on the heterogeneous surface. The isotherm is given by equation:

$$
Q_{e q}=K C_{e q}^{(1 / n)}
$$

where $Q_{e q}$ is the amount of sorbed As at equilibrium $(\mathrm{mg} / \mathrm{g}), K, n$ are the Freundlich empirical constants characterizing parameters and intensity of sorption process $(\mathrm{L} / \mathrm{g})$, and $C_{e q}$ is the As equilibrium concentration in solution $(\mathrm{mg} / \mathrm{L})$.

The Sips isotherm is a combined form of Langmuir and Freundlich expressions. The isotherm is given by equation:

$$
Q_{e q}=Q_{\max }\left(b C_{e q}\right)^{n} / 1+\left(b C_{e q}\right)^{n}
$$

where $Q_{e q}$ is the amount of sorbed As at equilibrium $(\mathrm{mg} / \mathrm{g}), b$ is the isotherm coefficient characterizing affinity of pyrogenic materials to As ions in solution $(\mathrm{L} / \mathrm{mg}), C_{e q}$ represents As equilibrium concentration in solution $(\mathrm{mg} / \mathrm{L}), n$ is the index of heterogeneity, and $Q_{\max }$ is the maximum sorption capacity at saturated binding sites of pyrogenic materials $\left(\mathrm{mg} / \mathrm{g}\right.$ ), which can be expressed also as $\mathrm{N}_{\mathrm{t}}$, which is a measure of total available binding sites per gram of pyrogenic materials.

\subsection{Sorbent Regeneration Study}

Regeneration studies were carried out in order to know the reusability of GSBC, A1GSBC and A2GSBC sorbents. As extraction agents $0.1 \mathrm{~mol} / \mathrm{L} \mathrm{HCl}$, and $0.1 \mathrm{~mol} / \mathrm{L} \mathrm{NaOH}$ in five sorption-desorption cycles were used. Experiments were performed by the sorption of As $(100 \mathrm{mg} / \mathrm{L}$ As) by GSBC, A1GSBC and A2GSBC ( $5 \mathrm{~g} / \mathrm{L})$. Sorptions of As were calculated according to Equation 1. Each sorption step was followed by desorption with selected desorption agent $(5 \mathrm{~g} / \mathrm{L})$ for $24 \mathrm{~h}$ at $22{ }^{\circ} \mathrm{C}$ and $120 \mathrm{~min}^{-1}$. After centrifugation (4000 1/min, $\left.5 \mathrm{~min}\right)$ and filtration, the concentrations of desorbed As in liquid phase were quantified.

\section{Results}

SEM analysis revealed the main differences in surface morphology of A1GSBC and A2GSBC (Figure 1a,b). The effects of $\mathrm{HNO}_{3}$ and air activation caused the visible opening of seed-biochar coat, and thus changes in external, internal surfaces, and porosity. Subsequent process of Fe-impregnation altered specific surface areas, volumes of micropores, and total Fe concentrations of studied materials (Table 1). Obtained results of total Fe showed higher effectiveness of material impregnation by Fe in the case of A2GSBC as compared to A1GSBC. SEM showed lower active iron phase on the external surface, since iron was found in internal chambers.

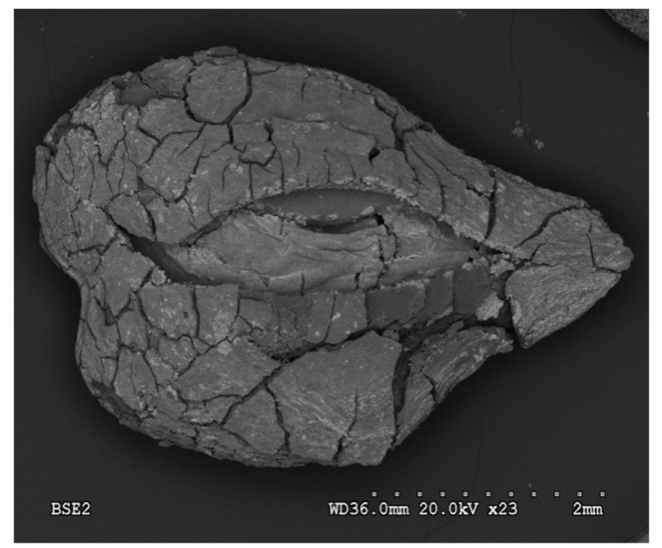

(a)

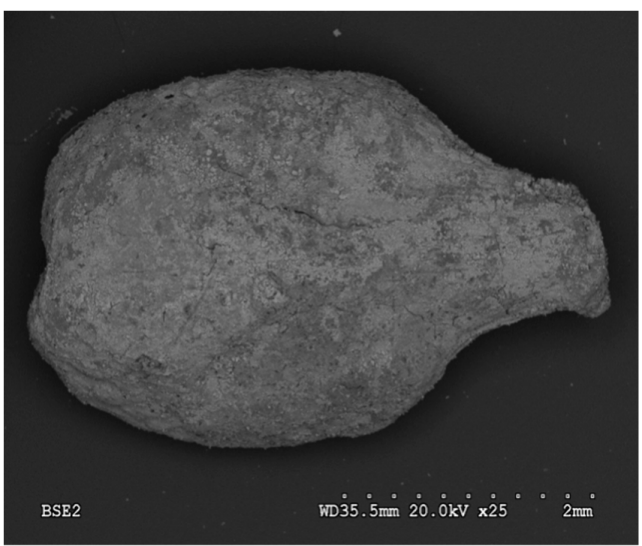

(b)

Figure 1. SEM images of air activated biochar (A1GSBC) (a) and $\mathrm{HNO}_{3}$ activated biochar (A2GSBC) (b). 
Table 1. Basic physico-chemical properties of Grape seeds (GS), GSBC, A1GSBC, and A2GSBC modified according Mena et al. (2017).

\begin{tabular}{|c|c|c|c|c|}
\hline & GS & GSBC & A1GSBC & A2GSBC \\
\hline$C(w t \%)$ & 55.8 & 81.8 & 73.8 & 69.0 \\
\hline $\mathrm{H}(\mathrm{wt} \%)$ & 6.8 & 2.2 & 2.1 & 2.4 \\
\hline$N(w t \%)$ & 2.3 & 1.9 & 2.6 & 3.1 \\
\hline$S(w t \%)$ & n.d. ${ }^{1}$ & n.d. ${ }^{1}$ & n.d. ${ }^{1}$ & n.d. ${ }^{1}$ \\
\hline $\mathrm{O}(\mathrm{wt} \%)$ & 31.6 & 4.7 & 9.5 & 14.6 \\
\hline Ash (\%) & 3.5 & 9.4 & 12.0 & 10.9 \\
\hline $\mathrm{SA}\left(\mathrm{m}^{2} / \mathrm{g}\right)$ & 42 & 405 & 416 & 348 \\
\hline $\mathrm{V}_{\text {micropores }}(\mathrm{mL} / \mathrm{g})$ & 0.01 & 0.14 & 0.15 & 0.12 \\
\hline $\mathrm{Fe}(\mathrm{wt} \%)$ & n.d. ${ }^{1}$ & n.d. ${ }^{1}$ & 2.8 & 4.7 \\
\hline As $(w t \%)$ & n.d. ${ }^{1}$ & n.d. ${ }^{1}$ & n.d. ${ }^{1}$ & n.d. ${ }^{1}$ \\
\hline
\end{tabular}

A2GSBC showed outer layer of iron and thin layer inside. Eventually, the low surface area of A2GSBC as compared to A1GSBC and GSBC indicates inner sphere pores blocking and plugging in process of Fe-impregnation. Similar results were shown by Mena et al. [18] (2017). Micháleková-Richveisová et al. [12] discovered a comparable trend of pore closing after Fe-impregnation for corn cobs-derived biochar. They discussed the lack in methods of porosity and surface area determination. Values of reached $\mathrm{pH} 8.1 \pm 0.1$ for GSBC, $5.5 \pm 0.1$ for A1GSBC, and $6.0 \pm 0.1$ for A2GSBC. EC decreased in order A1GSBC > A2GSBC > GSBC.

Total C content increased in order GSBC > A1GSBC > A2GSBC, which corresponds to changes in total $\mathrm{N}$ and $\mathrm{O}$ content. Fe-impregnation process added $-\mathrm{NO}_{3}$ functional groups in terms of $\mathrm{N}$ and $\mathrm{O}$ increasing. Total As analysis confirmed the negligible concentration in GSBC, A1GSBC, and A2GSBC.

Sorption behavior of As was studied under batch experimental conditions in terms of contact time and initial concentration of sorbate. Sorption process at initial As concentration represents relatively fast process with reached sorption equilibrium during $1440 \mathrm{~min}$ of contact time in the case of GSBC, A1GSBC, and A2GSBC. Obtained results (Figures 2a, 3a and 4a) confirmed two-phase process of As sorption separation by studied materials. First step of fast As sorption by carbonaceous materials within first $240 \mathrm{~min}$ of contact time is subsequently followed by second one until reaching sorption equilibrium at $1440 \mathrm{~min}$ of contact time. Second phase is characterized as slow and quantitative non-significant As uptake. Similar kinetic behavior was observed by Frišták et al. [10] at sorption separation of As by corn-cobs derived biochar. Fiol et al. [21] described the two-step sorption kinetic of selected elements by waste material.

Kinetic data of As sorption separation by GSBC, A1GSBC, and A2GSBC were evaluated and fitted by models of pseudo-first (Equation (2)), pseudo-second (Equation (3)), and pseudo-nth (Equation (4)) order. Model parameters that were obtained by non-linear regression analysis showed the best applicability of pseudo-nth order in comparison with pseudo-first and pseudo-second order for all three studied sorbents with coefficient of determinations (COD) $\geq 0.990$ (Table 2). Model of pseudo-nth order describes kinetic of adsorption processes of several chemicals with higher efficiency as compared to pseudo-first and second order model [22]. Kinetic processes of As sorption separation by GSBC, A1GSBC, and A2GSBC can be characterized by chemisorption as major controlling point. Similar results in As kinetic study were obtained for corn-cobs derived biochar in our previous study [10].

Correlation between As initial concentration in the reaction solution and the sorption potential of GSBC, A1GSBC, and A2GSBC was studied in the range 10-100 mg/L As at $\mathrm{pH} 5.5-6.0$. Our previous study [10] showed $\mathrm{H}_{2} \mathrm{AsO}_{4}{ }^{-}$as the predominant form at adjusted $\mathrm{pH}$. Mathematical models of Langmuir (Equation (5)), Freundlich (Equation (6)), and Sips (Equation (7)) adsorption isotherms were applied to describe and simulate sorption data. Equilibrium parameters that were obtained by non-linear regression analysis are listed in Table 3. Calculated values of COD showed that 
three-parametric Sips model as a combined Langmuir-Freundlich model can simulate sorption data with highest effectiveness. A comparison of two-parametric adsorption isotherm revealed the Langmuir model with a COD closer to 1.0. Based on these facts we can conclude hypothesis that surface charge of GSBC, A1GSBC, A2GSBC, and binding energy for anionic forms could be uniform $[10,12]$.

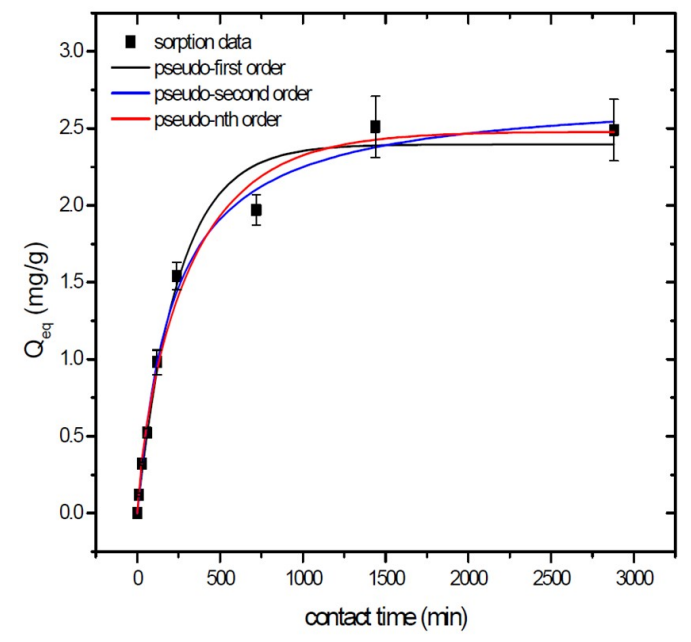

(a)

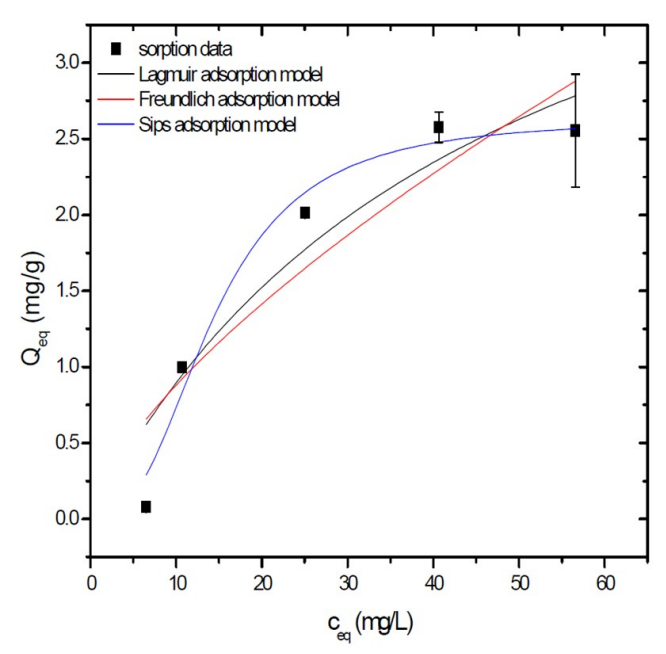

(b)

Figure 2. Sorption separation of As by GSBC with applied mathematical models of adsorption isotherms (a) and kinetic orders (b).

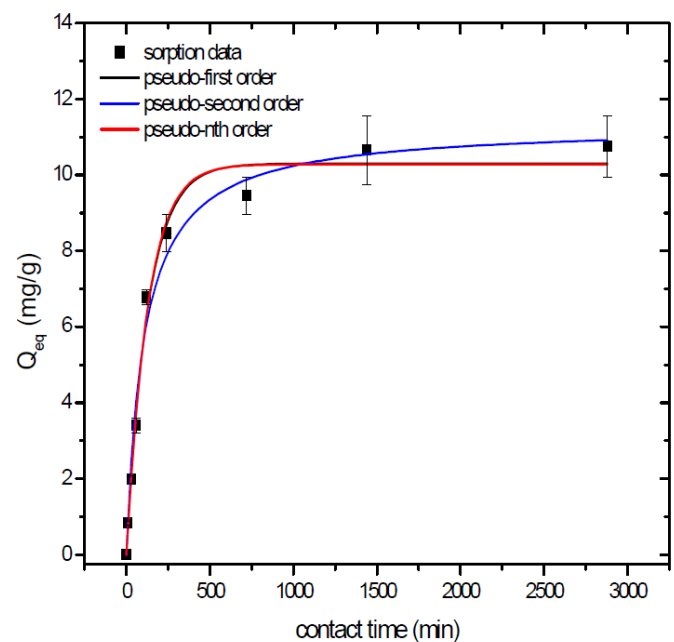

(a)

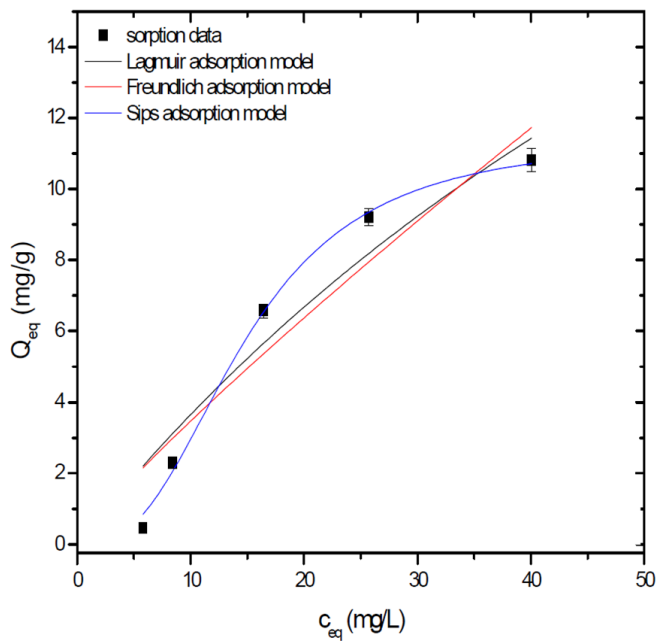

(b)

Figure 3. Sorption separation of As by A1GSBC with applied mathematical models of adsorption isotherms (a) and kinetic orders (b).

Table 2. Pseudo-first, pseudo-second and pseudo-nth order rate constants for As sorption separation by GSBC, A1GSBC, and A2GSBC.

\begin{tabular}{|c|c|c|c|c|c|c|c|c|c|}
\hline \multirow[b]{2}{*}{ Sorbent } & \multicolumn{3}{|c|}{$\begin{array}{c}\text { Pseudo-First Order Rate } \\
\text { Constants }\end{array}$} & \multicolumn{3}{|c|}{$\begin{array}{l}\text { Pseudo-Second Order Rate } \\
\text { Constants }\end{array}$} & \multicolumn{3}{|c|}{ Pseudo-Nth Order Rate Constants } \\
\hline & $\begin{array}{c}Q_{e q} \\
(\mathrm{mg} / \mathrm{g})\end{array}$ & $\begin{array}{c}k_{1} \\
(1 / \mathrm{min})\end{array}$ & $C O D$ & $\begin{array}{c}Q_{e q} \\
(\mathrm{mg} / \mathrm{g})\end{array}$ & $\begin{array}{c}k_{1} \\
\left(\mathrm{~g} / \mathrm{mg} \mathrm{min}^{-1}\right)\end{array}$ & COD & $\begin{array}{c}Q_{e q} \\
(\mathrm{mg} / \mathrm{g})\end{array}$ & $\begin{array}{c}k_{1} \\
\left(\mathrm{~g} / \mathrm{mg} \mathrm{min}^{-1}\right)\end{array}$ & $C O D$ \\
\hline GSBC & 2.390 & 0.004 & 0.985 & 2.734 & 0.002 & 0.990 & 2.479 & 0.002 & 0.993 \\
\hline A1GSBC & 10.301 & 0.008 & 0.990 & 11.313 & 0.001 & 0.987 & 10.277 & 0.009 & 0.992 \\
\hline A2GSBC & 7.936 & 0.014 & 0.977 & 8.565 & 0.002 & 0.979 & 7.895 & 0.017 & 0.990 \\
\hline
\end{tabular}




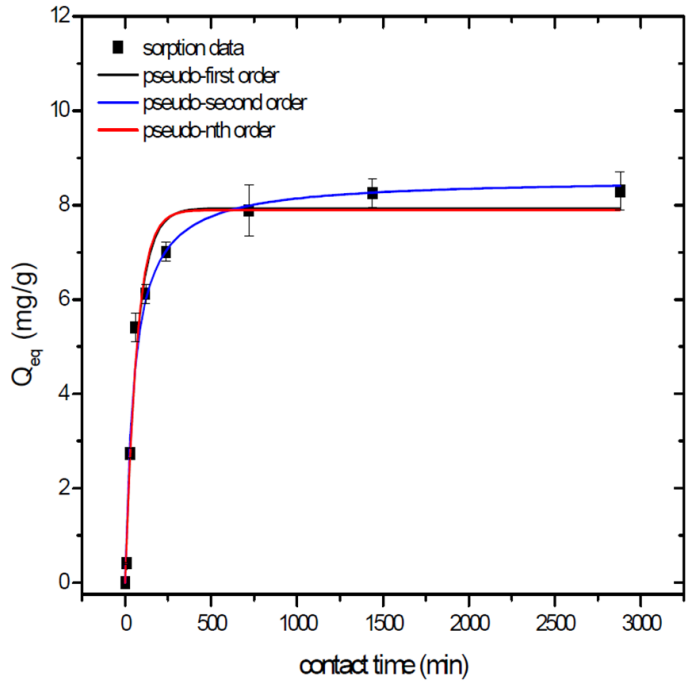

(a)

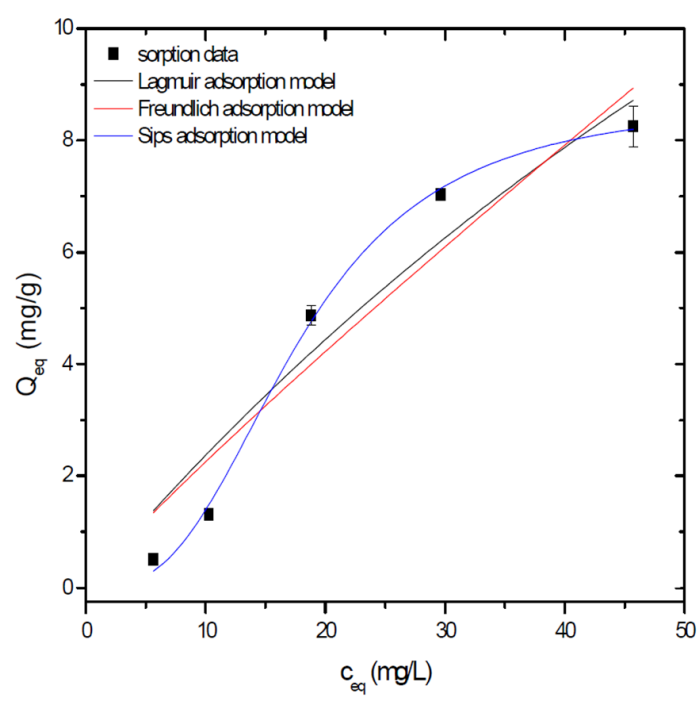

(b)

Figure 4. Sorption separation of As by A2GSBC with applied mathematical models of adsorption isotherms (a) and kinetic orders (b).

Table 3. Langmuir, Freundlich and Sips equilibrium parameters for As sorption separation by GSBC, A1GSBC, and A2GSBC obtained by non-linear regression analysis.

\begin{tabular}{ccccccccccc}
\hline & \multicolumn{3}{c}{ Langmuir } & \multicolumn{3}{c}{ Freundlich } & \multicolumn{4}{c}{ Sips } \\
\hline Sorbent & $\begin{array}{c}\boldsymbol{Q}_{\max } \\
(\mathbf{m g} / \mathbf{g})\end{array}$ & $\begin{array}{c}\boldsymbol{B} \\
(\mathbf{L} / \mathbf{m g})\end{array}$ & $\mathbf{C O D}$ & $\begin{array}{c}\boldsymbol{K} \\
(\mathbf{L} / \mathbf{g})\end{array}$ & $\boldsymbol{n}$ & $\mathbf{C O D}$ & $\begin{array}{c}\boldsymbol{Q}_{\max } \\
(\mathbf{m g} / \mathbf{g})\end{array}$ & $\begin{array}{c}\boldsymbol{B} \\
(\mathbf{L} / \mathbf{m g})\end{array}$ & $\boldsymbol{n}$ & $\boldsymbol{C O D}$ \\
\hline GSBC & 5.082 & 0.021 & 0.904 & 0.182 & 0.684 & 0.861 & 2.633 & 0.0008 & 2.656 & 0.979 \\
A1GSBC & 39.443 & 0.007 & 0.928 & 0.457 & 0.907 & 0.916 & 11.438 & 0.0002 & 2.927 & 0.998 \\
A2GSBC & 34.903 & 0.010 & 9.923 & 0.287 & 0.879 & 0.907 & 8.706 & 0.0006 & 2.706 & 0.994 \\
\hline
\end{tabular}

Sorption efficiency as a mean of calculated $Q_{\max }$ values based on Langmuir adsorption model increased in order GSBC $<$ A2GSBC $<$ A1GSBC (Table 3). The process of GSBC activation by air A1GSBC and acid treatment A2GSBC with subsequent Fe-impregnation improved the sorption potential for As by about more than 7.7 times and 6.8 times, respectively. Comparison of obtained results with physico-chemical properties of studied materials showed the crucial effect of surface area and pore volumes on the As sorption separation process (Table 1). The effect of iron impregnation can be considered to be negligible in this study.

The regeneration ability of sorbents was studied to know the reusability of GSBC, A2GSBC, and A1GSBC in separation studies. Obtained results showed the better applicability of alkali desorption agent as compared to hydrochloric acid (Table 4). The percentage regeneration of As separated from the reaction solution by the studied materials during five steps of the sorption-desorption cycle resulted about $97 \%$ for GSBC, $94 \%$ for A1GSBC, and $92 \%$ for A2GSBC. In the case of $\mathrm{HCl}$ as As desorption eluent, the crucial decreasing of sorption ability was showed. Acid agent can significantly damage sorption sites, protonate active surfaces of sorption materials, and remove easily extractable forms of Fe and fine structures [3]. Therefore fourth and fifth steps of regeneration were not effective. This fact was highlighted and described in detail in our previous study [10]. 
Table 4. Reusability and regeneration of GSBC, A1GSBC, and A2GSBC (experimental conditions: dose $5 \mathrm{~g} / \mathrm{L}$, sorption (S)/desorption (D) time $24 \mathrm{~h}$, desorption agent: $0.1 \mathrm{~mol} / \mathrm{L} \mathrm{HCl}$ (a), and $0.1 \mathrm{~mol} / \mathrm{L}$ $\mathrm{NaOH}(\mathrm{b})$, temperature $22{ }^{\circ} \mathrm{C}$, stirring $120 \mathrm{rpm}$.

\begin{tabular}{|c|c|c|c|c|c|c|c|c|c|c|c|}
\hline \multirow{3}{*}{$\begin{array}{l}\text { Desorption } \\
\text { Agent }\end{array}$} & \multirow{3}{*}{ Sorbent } & \multicolumn{10}{|c|}{$Q_{e q}(\mathrm{mg} / \mathrm{g})$ in Each Number of Sorption-Desorption Cycle } \\
\hline & & \multicolumn{2}{|c|}{1} & \multicolumn{2}{|c|}{2} & \multicolumn{2}{|c|}{3} & \multicolumn{2}{|c|}{4} & \multicolumn{2}{|c|}{5} \\
\hline & & $\mathbf{S}$ & D & $\mathbf{S}$ & D & $\mathbf{S}$ & $\mathbf{D}$ & $\mathbf{S}$ & $\mathbf{D}$ & $\mathbf{S}$ & $\mathbf{D}$ \\
\hline \multirow{3}{*}{$\mathrm{HNO}_{3}$} & GSBC & $2.5^{* * *}$ & $\begin{array}{l}1.8^{* * *} \\
(72 \%)\end{array}$ & $2.0^{* * *}$ & $\begin{array}{l}1.5^{* * *} \\
(75 \%)\end{array}$ & $1.4^{*}$ & $\begin{array}{l}1.0^{*} \\
(71 \%)\end{array}$ & $0.6^{* * *}$ & $\begin{array}{l}0.2^{* * *} \\
(33 \%)\end{array}$ & n.d. & n.d \\
\hline & A1GSBC & $10.7^{* * *}$ & $\begin{array}{l}8.6^{* * *} \\
(80 \%)\end{array}$ & $5.2 *$ & $\begin{array}{l}3.2^{* * *} \\
(62 \%)\end{array}$ & $3.1^{* * *}$ & $\begin{array}{l}0.8^{*} \\
(26 \%)\end{array}$ & n.d. & n.d & n.d. & n.d \\
\hline & A2GSBC & $8.2^{* * *}$ & $\begin{array}{l}5.4^{* * *} \\
(66 \%)\end{array}$ & 4.7 & $\begin{array}{l}2.6^{* * *} \\
(55 \%)\end{array}$ & $1.3^{*}$ & $\begin{array}{l}0.4^{* * *} \\
(31 \%)\end{array}$ & n.d. & n.d & n.d. & n.d \\
\hline \multirow{3}{*}{$\mathrm{NaOH}$} & GSBC & $2.5^{* * *}$ & $\begin{array}{l}1.9^{* * *} \\
(76 \%)\end{array}$ & $2.4^{* * *}$ & $\begin{array}{l}2.3^{* * *} \\
(85 \%)\end{array}$ & $2.3^{* * *}$ & $\begin{array}{l}2.3^{* * *} \\
(100 \%)\end{array}$ & $2.4^{* * *}$ & $\begin{array}{l}1.8^{* * *} \\
(75 \%)\end{array}$ & $2.0^{* * *}$ & $\begin{array}{l}1.4^{* * *} \\
(70 \%)\end{array}$ \\
\hline & A1GSBC & $10.8^{* * *}$ & $\begin{array}{c}10.7^{* * *} \\
(99 \%)\end{array}$ & $10.7^{* * *}$ & $\begin{array}{c}10.4^{* * *} \\
(97 \%)\end{array}$ & $10.1^{* * *}$ & $\begin{array}{l}9.4^{* * *} \\
(93 \%)\end{array}$ & $9.5^{* * *}$ & $\begin{array}{l}8.7^{* * *} \\
(92 \%)\end{array}$ & $9.4^{* * *}$ & $\begin{array}{l}8.4^{* * *} \\
(89 \%)\end{array}$ \\
\hline & A2GSBC & $8.1^{* * *}$ & $\begin{array}{l}7.8^{* * *} \\
(96 \%)\end{array}$ & $7.9^{* * *}$ & $\begin{array}{l}7.6^{* * *} \\
(96 \%)\end{array}$ & $7.9^{* * *}$ & $\begin{array}{l}7.3^{* * *} \\
(92 \%)\end{array}$ & $7.0^{* * *}$ & $\begin{array}{l}6.8^{* * *} \\
(97 \%)\end{array}$ & $5.7^{* * *}$ & $\begin{array}{l}5.1^{* * *} \\
(89 \%)\end{array}$ \\
\hline
\end{tabular}

n.d. means concentration under detection limit of applied analytical method. Stars represent statistical significance of data based on $t$-test $\left({ }^{*}\right.$ means $p<0.05,{ }^{* * *}$ means $\left.p<0.001\right)$.

\section{Conclusions}

The physical and chemical activation of grape seeds-derived biochar and the application of prepared materials in the separation process of As from aqueous solutions were presented. The processes of air activation, acid treatment, and subsequent Fe-impregnation of biochar-based sorbents provide an option to produce stable and effective sorbent. The sorption process of As by studied materials is a potentially fast process with reached equilibrium in $1440 \mathrm{~min}$. The effect of physical and chemical activation caused significant increasing of sorption capacities by about 6.8-7.7 times. The application of activated carbon based sorbents in separation processes of anionic forms represents a low-cost and promising tool in the pre-concentration of weak concentrated metalloids from liquid wastes.

Author Contributions: V.F., E.M.-J. and T.F. conceived and designed the sorption separation experiments, E.D. produced biochar sorbents, V.F. and E.D. performed sorbent characterization experiments, V.F. and E.M.-J. contributed analysis tools, V.F. wrote the paper.

Funding: This research was funded by Trnava University in Trnava, grant number 9/TU/2018.

Acknowledgments: Authors are thankful to Ismael Fernandez Mena for support in SEM analysis, to Jana Fančovičová for statistical analysis and Stephen Bell for language proof.

Conflicts of Interest: The authors declare no conflict of interest.

\section{References}

1. Tarvainen, T.; Albanese, S.; Birke, M.; Poňavič, M.; Reimann, C. The GEMAS Projet Team. Arsenic in agricultural and graying land soils of Europe. Appl. Geochem. 2013, 28, 2-10. [CrossRef]

2. Mandal, S.; Sahu, M.K.; Patel, R.K. Adsorption studies of arsenic(III) removal from water by zirconium polyacrylamide hybrid material (ZrPACM-43). Water Resour. Ind. 2013, 4, 51-67. [CrossRef]

3. Mohan, D.; Pittman, C.H.U. Arsenic removal from water/wastewater using adsorbents-Acritical review. J. Hazard. Mater. 2007, 142, 1-53. [CrossRef] [PubMed]

4. Pipíška, M.; Micháleková-Richveisová, B.; Frišták, V.; Horník, M.; Remenárová, L.; Stiller, R.; Soja, G. Sorption separation of cobalt and cadmium by straw-derived biochar: Aradiometric study. J. Radioanal. Nucl. Chem. 2017, 311, 85-97. [CrossRef]

5. Aranda, P.R.; Llorens, I.; Perino, E.; de Vito, I.; Raba, J. Removal of arsenic (V) ions from aqueous media by adsorption on multiwall carbon nanotubes thin film using XRF technique. Environ. Nanotechnol. Monit. Manag. 2016, 5, 21-26. [CrossRef] 
6. Shakoor, M.B.; Niazi, N.K.; Bibi, I.; Shahid, M.; Sharif, F.; Bashir, S.; Shaheen, S.M.; Wang, H.; Tsang, D.C.W.; Ok, Y.S.; et al. Arsenic removal by natural and chemically modified watermelon rind in aqueous solutions and groundwater. Sci. Total. Environ. 2018, 645, 1444-1455. [CrossRef] [PubMed]

7. Sepúlveda, P.; Rubio, M.A.; Baltazar, S.E.; Rojas-Nunez, J.; Sánchez-Llamazares, J.L.; Garcia, A.G.; Arancibia-Miranda, N. As (V) removal capacity of Fe Cu bimetallic nanoparticles in aqueous solutions: The influence of $\mathrm{Cu}$ content and morphologic changes in bimetallic nanoparticles. J. Colloid Interface Sci. 2018, 524, 177-187. [CrossRef] [PubMed]

8. Pan, H.; Hou, H.; Chen, J.; Li, H.; Wang, L. Adsorption of arsenic on iron modified attapulgite (Fe/ATP): Surface complexation model and DFT studies. Adsorption 2018, 24, 459-469. [CrossRef]

9. Bakshi, S.; Banik, C.; Rathke, S.J.; Laird, D.A. Arsenic sorption on zero-valent iron-biochar complexes. Water Res. 2018, 137, 153-163. [CrossRef] [PubMed]

10. Frišták, V.; Micháleková-Richveisová, M.; Víglašová, E.; Ďuriška, L.; Galamboš, M.; Moreno-Jimenéz, E.; Pipíška, M.; Soja, G. Sorption separation of Eu and As from single-component systems by Fe-modified biochar: Kinetic and equilibrium study. J. Iran. Chem. Soc. 2017, 14, 521-530. [CrossRef]

11. Podder, M.S.; Majumder, C.B. Kinetic, mechanistic and thermodynamic studies of removal of arsenic using Bacillus arsenicus MTCC 4380 immobilized on surface of granular activated carbon/ $\mathrm{MnFe}_{2} \mathrm{O}_{4}$ composite. Groundw. Sustain. Dev. 2016, 2-3, 53-72. [CrossRef]

12. Micháleková-Richveisová, B.; Frišták, V.; Pipíška, M.; Ďuriška, L.; Moreno-Jimenéz, E.; Soja, G. Iron-impregnated biochars as effective phosphate sorption materials. Environ. Sci. Pollut. Res. 2017, 14, 521-530. [CrossRef] [PubMed]

13. Lehmann, J.; Joseph, S. Biochar for Environmental Management: Science, Technology and Implementation; Earthscan from Routlenge: London, UK, 2015; ISBN 978-0-415-70415-1.

14. Frišták, V.; Pipíška, M.; Soja, M. Pyrolysis treatment of sewage sludge: A promising way to produce phosphorus fertilizer. J. Clean Technol. 2018, 172, 1772-1778. [CrossRef]

15. Azargohar, R.; Dalai, A.K. Steam and KOH activation of biochar: Experimental and modeling studies. Microporous Mesoporous Mater. 2008, 110, 413-421. [CrossRef]

16. Frišták, V.; Friels-Hanl, W.; Pipíška, M.; Richveisová-Micháleková, B.; Soja, G. The response of artificial aging to sorption properties of biochar for potentially toxic heavy metals. Nova Biotechnologica et Chimica 2014, 13, 137-147. [CrossRef]

17. Shim, T.; Yoo, J.; Ryu, Ch.; Park, Y.K.; Jung, J. Effect of steam activation of biochar produced from a giant Miscanthus on copper sorption and toxicity. Biores. Technol. 2015, 197, 85-90. [CrossRef] [PubMed]

18. Mena, I.F.; Diaz, E.; Rodriquez, J.J.; Mohedano, A.F. CWPO of bisphenol A with iron catalysts supported on microporous carbons from grape seeds activation. Chem. Eng. J. 2017, 318, 153-160. [CrossRef]

19. Enders, A.; Lehmann, J. Comparison of wet/digestion and dry-ashing methods for total elemental analysis of biochar. Commun. SoilSci. Plant. 2012, 43, 1042-1052. [CrossRef]

20. OECD-Guideline 106. OECD Guideline for the Testing of Chemicals. Adsorption-Desorption Using a Batch Equilibrium Method; Organisation for Economic Co-operation and Development (OECD): Paris, France, 2001.

21. Fiol, N.; Villaescusa, I.; Martínez, M.; Miralles, N.; Poch, J.; Serarols, J. Sorption on Ni (II), Cu (II) and Cd (II) from aqueous solution by olive stone waste. Sep. Purif. Technol. 2006, 50, 132-140. [CrossRef]

22. Azizian, S.; Fallag, R.N. A new empirical rate equation for adsorption kinetics at solid/solution interface. Appl. Surf. Sci. 2010, 256, 5153-5156. [CrossRef]

(C) 2018 by the authors. Licensee MDPI, Basel, Switzerland. This article is an open access article distributed under the terms and conditions of the Creative Commons Attribution (CC BY) license (http://creativecommons.org/licenses/by/4.0/). 